ÉGYPTE

monde arabe

\section{Égypte/Monde arabe}

23 | 2021

Memory, Storytelling and Space

\title{
Biancani Francesca, Sex Work in Colonial Egypt: Women, Modernity and the Global Economy
}

Mina Ibrahim

\section{(2) OpenEdition \\ 1 Journals}

Electronic version

URL: https://journals.openedition.org/ema/14814

DOI: 10.4000/ema.14814

ISSN: 2090-7273

Publisher

CEDEJ - Centre d'études et de documentation économiques juridiques et sociales

\section{Printed version}

Date of publication: 2 December 2021

Number of pages: 207-209

ISBN: 978-2-900956-26-7

ISSN: 1110-5097

\section{Electronic reference}

Mina Ibrahim, "Biancani Francesca, Sex Work in Colonial Egypt: Women, Modernity and the Global Economy", Égypte/Monde arabe [Online], 23 | 2021, Online since 02 December 2021, connection on 07 July 2022. URL: http://journals.openedition.org/ema/14814 ; DOI: https://doi.org/10.4000/ema.14814 


\section{FRANGESGA BIANGANI, SEX WORK IN COLONIAL EGYPT: \\ WOMEN, MODERNITY AND THE GLOBAL ECONOMY, LONDON-NEW YORK, I.B. TAURIS, 2018}

The absence of licensed brothels in today's Cairo is haunted by the stories presented in Francesca Biancani's monograph. Through an extensive archival work supported by an anthropological eye, she investigates a currently invisible phenomenon that was once a subject of many legal debates and disputes among different political, economic, social, and religious forces- colonial, foreign, and national ones alike. Using pictures, songs, and novels that describe these times as well, the book highlights an important, yet overlooked historical account of the modern Egyptian state and its connection to transnational moving bodies and money. "[S]cattered voices and perceptions of sex workers" (p. 95) complicate the masculinized repeal of regulated prostitution by the end of the 1940s. We get sense of how sex workers "resist or renegotiate the terms of their exploitation" (p. 99), while stressing how the abolition of legalized sex work was a form of nonconsensual, hegemonic political and social order that dismissed the agency of the female subaltern.

"The first law disciplining sex work was drafted in Egypt on 31 October 1882, that is, only a month-and-a-half after...the occupation of Egypt" (p. 50). Resembled as a 'white man's burden' to offer a "safe environment" (p. 51) for sex workers and for the society in general, this law and other subsequent ones such as the "1916 purification" (p. 118) further increased the power of the (colonial) state authorities to count and to control the everydayness of people's (sexual) interactions. As anthropologists and social-cultural historians of modernity and of modern states reflect in their scholarship, the colonial encounter was a crucial moment in history when European occupants could impose their 'civilizing' mission. Biancani argues that beyond the well-studied street demonstrations and party politics, local reaction(s) to colonial policies can be studied from overlooked spaces such as bars, casinos, and 
brothels. Sex workers found their ways to contest and to contribute to the making of Egypt's labor force and urban transformation through their mobilization trends and gatherings. Moreover, as much as "[m]any prostitutes tried to escape from supervision by pretending to be artists and frequenting the music halls," the presence of sex workers among 'other honorable and decent' Egyptians paradoxically haunted and helped "the making of a disciplined public space" (p. 44). "[A]s long as the public order was not disrupted, and no complaints were raised by the people living nearby, public security officials were happy to turn a blind eye on clandestine sex work" (p. 45).

In a similar vein, "prostitution and its regulation were absolutely integral to the production of the colonial order in Cairo" (p. 11). Ethnicity and race in specific were constructed as determinants of sex work practice [and its legalization] by the very same institutions of colonial control" (p. 67). For instance, foreign sex workers were subjects of the Capitulations system that prevented local courts from punishing foreigners. Moreover, while Egyptian prostitutes were dehumanized by European communities, the latter perceived 'white' European prostitutes as innocent victims of a cruel world. In this regard, the daily movements and agencies of sex workers- Egyptians and foreigners alikeare also opportunities for Biancani and her readers to learn about how systems of law, order, and punishment in Egypt can be compared to and situated into an unequal, global system of (colonial) incarceration and governance. This is true not only while looking into "the racial, hegemonic discourse of the elites" (p. 107), but also by illustrating the challenging "class-based cooperation between native and 'white' subalterns" (ibid.).

Although the regulation of sex work was challenged from below during colonial times, its abolition did not mean a full, ultimate disappearance of the phenomenon. The nationalist movement that led the abolition of licensed sex work just before the 1952 July Revolution in Egypt left a lot of unresolved complexities. For example, given that "the number of licensed sex workers... or caught in the streets while soliciting has always exceeded the number of registered women" (p. 56), not all the women were subjects to the medical checkups that sex workers had to have to be visible before the state. Hence, if the registered women crystallized "parallelism between sex work regulation and the institutionalization of modern medicine, and the medical profession, under colonial domination" (p. 60), the unregistered ones who did not want to get a license from the official institutions also reflected sex workers' tactics to hide from and to reflect the deficiency of the state's tools of regulation. Within this context, Biancani's book opens the door for other researchers to further investigate where sex workers went after the abolition, that is, after they were all prevented from having official medical check-ups. This is especially the case during the nationalist state of Gamal Abdel Nasser and in light of the Islamist movements that flourished after his death.

Indeed, the abolition of legalized sex work ended just one phase of modern prostitution in Egypt. In addition to the issue of public health, the 1951 
abolition did not put an end to the critical debate of how (Egyptian) women should act in public. Of course, as the author teaches us, public health and (women's) public morality were "fundamental themes of the abolitionist campaign and in public discourse from the 1920s onwards" (p. 171). However, although the political decision of abolishing sex work might be read as a victory of those who tended to moralize the Egyptian society, it can be rather analyzed as an arbitrary bourgeois resolution performed by certain actors who left the financial grievances of sex workers untouched. Put differently, "prostitution was not only the labor of women coming from 'morally degenerated' working-class families...more accurately, it was the labor of women coming from economically weak, patriarchal families" (p. 27). Thus, as the materialization of moral codes complicates the clarity of their romanticized, abstract definitions, a political masculine decision enforced by keepers of Egypt's 'honor' will be always haunted by the grievances and impoverishment of sex workers, particularly after the abolishment.

In short, Francesca Biancani's book goes hand in hand with another recent monograph published by historian Omar D. Foda (2019). Egypt's Beer: Stella, Identity and the Modern State also tells the story of modern, colonial, and national Egypt through negated practices. Unlike prostitution, it is true that, until today, alcohol is legally produced and consumed in Egypt in some places and during certain times. However, like sex workers, Egyptians with drinking habits have been usually excluded from narrating the Egyptian history. As someone who earned his school education in Egyptian public schools, I have learned that modern Egyptian history should be told in 'virgin' and 'sober' manners. Consequently, Biancani's insistence to reflect voices of sex workers is a challenge to mainstream history that regards some figures and interactions as haunting misfits to their moral perfection.

One thing this book (and also the literature about such haunting subjects in general) could have been benefited from is to consider the stances taken by local Christian institutions and communities towards sex workers and prostitution. In the same way Biancani reflects the positioning of the Muslim Brethren and the Christian foreign missionaries, it would be a great addition to investigate, for example, the social and theological controlling and regulation practiced by the Coptic Orthodox Church. 